\title{
PSYCHOSOCIAL IMPACT OF SICKLE CELL DISEASE ON MOTHERS OF AFFECTED CHILDREN SEEN AT UNIVERSITY OF ILORIN TEACHING HOSPITAL, ILORIN, NIGERIA
}

\author{
M.F. TUNDE-AYINMODE
}

\begin{abstract}
Background: Attention paid to psychological disorders of mothers or families of children suffering from sickle cell disease ( $\mathrm{SCD}$ ) in Nigeria has been inadequate.

Objective: To assess the psychosocial impact of SCD on mothers of affected children and two control samples.

Design: A cross-sectional controlled study.

Setting: University of Ilorin Teaching Hospital, Ilorin, Nigeria.

Subjects: One hundred mothers of SCD affected children (SCD children) were the study sample while the controls were made of 75 mothers of children with bronchial asthma (asthmatics) anci 75 mothers of children with some acute medical illness (AMI).

Results: The mothers of children with SCD (SCD mothers) were significantly likely to report burden in the areas of finance, time consumption and hindrance from enjoyment of live and were also more likely to over-protect their children. A total of $28 \%$ of SCD mothers were identified as probable cases with psychological problems on SRQ compared to $20 \%$ and $25 \%$ of mothers of asthmatics and AMI children respectively, this differences were, however, not statistically significant. Conclusion: As a result of the prevalent psychosocial impact of this disease on mothers it is strongly suggested that special consideration in terms of routine psychosocial assessment and treatment be incorporated into the various levels of health care system. There is also the need to encourage the establishment of more social organisations like SCD clubs where affected families can interact and counsel one another.
\end{abstract}

\section{INTRODUCTION}

The fact that childhood physical illness impact on family functioning has been well described (1-4). This is not surprising because the family is principal agent of socialisation whose structure and functioning may affect the child's adjustment to physical illness (5).

The components of functioning family are committed to the promotion of psychosocial and physical well being of one another (6), making it possible for disease in one impacting on the other.
Psychosocial impact of physical illness is a dynamic process, which may replicate. When an individual behaves in a way to change an impact he may simultaneously create another. For example the taking on of extra work by a mother of an SCD patient to reduce the financial burden of SCD may mean an increased risk of physical, social and emotional neglect of her family with consequent marital disharmony. Psychosocial impact is considered a problem because it may cause significant distress $(7,8)$. 
Parents of the physically ill child may be restricted in terms of time available for social interaction and consequently at risk of marital disharmony $(4,9)$. They may experience absenteeism from work and lose of business opportunities with attendant risk of financial difficulties. These problems have been linked to $\operatorname{SCD}(2,3)$ and bronchial asthma (4).

Sickle cell disease is a condition that is debilitating, incurable and may run a variable course with episodes called crises. These are usually with pain and anaemia, which can sometimes be life threatening requiring hospital admissions and blood transfusions, with considerable stress on parents. Bronchial asthma is a respiratory disease, which also runs a chronic and variable course with acute attacks that are intermittent and seasonal (10). It could also be life threatening or fatal if not properly managed and may result into frequent hospital visits and in some cases admissions (11). Acute medical illnesses in children are diseases of short duration which may be major or minor requiring hospital admissions or not and may also be life threatening or fatal. Depending on severity and mode of management they may cause some degree of psychosocial distress to the child and his family (12).

In terms of family adjustment it was reported in one study in Nigeria (13) that $40 \%$ of mothers of SCD children felt sad because of the disease. In another study $80 \%$ of mothers felt that their children's SCD affected their working lives, 93\% their marriage and $50 \%$ their physical health (2). Psychological problems such as anger, grief, depression, guilt, and fears have also been described (1-3,14). Family and psychological dysfunction above normal controls have also been reported in parents of asthmatic children $(4,15)$.

This paper is derived from a parent study aimed at assessing the psychosocial problems experienced by children with SCD and their families (16). In this paper the findings on the psychosocial problem of mothers of SCD children will be examined and compared with those of mothers of asthmatics and of children with some acute medical conditions. Many previous studies $(1-3,9,14)$ have described the negative psychosocial impact of SCD on affected children and their families. This paper tries to examine whether there are any characteristics or peculiar problems (in terms of scope and severity) exerted via SCD by comparing mothers, of affected children with those of children with bronchial asthma (a chronic and relatively burdensome condition) and some acute medical conditions.

\section{MATERIALS AND METHODS}

Recruitment and selection of sample: 'The parent study was a controlled investigation involving $100 \mathrm{SCD}$ children, 75 children each with bronchial asthma (asthmatics) and some acute medical conditions (AMI children) and their mothers, the former as the study group, the latter two the control groups. The samples were recruited from the Paediatric SCD and Chest clinics and the General Outpatient Department (GOPD) of the University of Ilorin Teaching Hospital, Ilorin.

All consecutive children and their biological mothers (all the mothers were physically healthy and had no previous history of mental illness) visiting the above clinics during the period of the study that met the inclusion criteria and gave consent were assessed. The inclusion and exclusion criteria with other details of the children findings including the application of Children Behaviour Questionnaire (CBQ) Parent version or Rutter Scale $\mathrm{A} 2$ are reported elsewhere (17).

Instruments: The socio-demographics of the mothers were collected using a semi-structured questionnaire and the Self Reporting Questionnaire (SRQ) was used to assess for psychological disorder. The SRQ was constructed for use in the WHO study on strategies for extending mental health care. It is especially designed for screening of psychiatric disturbances in the primary care setting (18). The SRQ-1 or 20-item version was used, each item in the questionnaire is answered "No" or "Yes" and has a score of 0 or 1 respectively.

SRQ- 1 was validated in a primary care setting in rural South Western Nigeria and found to effectively discriminate between patients with and without psychiatric morbidity. This was best done at a cutoff point of 5, which has the optimal sensitivity of $(98.8 \%)$ and specificity of $(90.9 \%)$. This cut-off point of 5 was also used by Ohaeri et al (20) in a study for assessing the prevalence of psychiatric morbidity among attendees of five primary health care centres in five towns of a rural Local Government Area in South Western Nigeria.

Instrument translation and pilot testing: Translation of the instrument and questionnaire to the local Yoruba language and back translation to English language was done and few areas of disparity were harmonised. 
Both versions of the instruments were pilottested using 25 mothers ( 10 mothers of SCD, 5 with asthma and 10 with AMI) selected from two hospitals (other than UITH) in Ilorin. The pilot-testing exercise revealed that most of the items measured were comprehensible and easy to complete, and could be administered within 20 to 30 minutes. The author and two trained assistants administered the instruments.

Data analysis: Data analysis was carried out using EPI-info version 6. Simple frequency tables obtained and Chi-square tests were performed to determine significant differences between various variables and correlates. Means of some variables were calculated and compared using ANOVA. The preliminary analysis of the rating of effects on the socio-demographic questionnaire ("a little", "moderately", "much") yielded invalid Chi-square results (that is at least one expected value was less than 5) hence the effects were merged into "no effect" and "some effects". Statistical significant difference was set at $\mathrm{P}$-value $<0.05$.

\section{RESULTS}

A total of 250 mothers ( 100 mothers of SCD children, 75 each of asthmatic and AMI children) were assessed. Twenty four mothers of 11 SCD children, four asthmatic children and nine AMI children did not give their consent to participate in the study due to lack of interest and having no time to spare.

Table 1 shows the socio-demographic and family characteristics of the three groups of mothers. Using ANOVA statistical test, the mean (mean: standard deviation) of mothers' age ( $\mathrm{SCD}=39.010: 6.303$ vs Asthma $=37.680: 6.797$ vs $\mathrm{AMI}=36.907: 6.163$, P. value $=0.090)$, number of mothers' children (SCD $=4.680: 1.595$ vs Asthma $=4.600: 1.533$ vs $\mathrm{AMI}=$ 4.773: $1.689, \mathrm{P}$-value $=0.804$ ) and number of fathers' children $(\mathrm{SCD}=6.380: 3.706$ vs Asthma $=6.027: 3.472$ vs $A M I=6.120: 3.242$, P-value $=0.784$ ) for the three groups were compared. All the variables assessed were not statistically significantly different.

In Table 2 mothers of SCD children significantly reported more burden in all the variables assessed except for three items which are: "feeling that their other children resent the time spent with the patient", "child using illness to seek attention", and "using illness to manipulate to get wants".

In Table 3 the item "feeling unhappy" had the highest score among the 250 mothers $(101,40 \%)$, however only $4 \%$ of these mothers had a score on the item "has the thought of ending your life been in your mind". Mothers of SCD children were significantly more likely to "feel unhappy", "have poor digestion", "find it difficult to enjoy daily activities and "feel that their daily work was suffering because of their child's illness".

The range of total score on SRQ was 0 to 19 . Three quarters of mothers scored below the cut off point of 5 . Twenty eight $(28 \%)$ mothers of SCD children, $15(20 \%)$ mothers of asthmatic children and $19(25 \%)$ mothers of AMI children were identified as probable cases with psychological problem (that is SRQ score of 5 and above). There was no significant difference between the groups when compared in terms of the SRQ scores.

In Table 4, probable cases and non-cases on SRQ in each of the groups were compared on selected socio-demographic and psychological variables. For the SCD group probable cases were more likely to be mothers with low education and having male children with the disease. In all the groups, mothers identified as probable cases with psychological problems were also significantly more likely to have their children identified as probable cases with psychological problems on Rutter Scale A2. Probable cases identified by SRQ $(\mathrm{SCD}=28(28 \%) ;$ Asthma $=15(20 \%) ; \mathrm{AMI}=19(25 \%)$ were also compared in terms of means of some variables using ANOVA statistical test. These items are mean (mean: standard deviation) of mothers' age $(\mathrm{SCD}=40.250: 5.929$ vs Asthma = $37.571: 7.013$ vs $\mathrm{AMI}=36.700: 6.267$, P-value $=0.137$ ), number of mothers' children $(\mathrm{SCD}=4.679: 1.634$ vs Asthma $=$ 4.643: 1.823 vs $\mathrm{AMI}=4.400: 1.847, \mathrm{P}$-value $=0.852$ ) and number of fathers' children ( $S C D=6.643: 3.369$ vs Asthma $=7.143: 4.074$ vs $\mathrm{AMI}=6.950: 4.16$, $\mathrm{P}$-value $=0.914$ ). All the variables assessed were not statistically significantly different. 
Table 1

Socio-demographic and family characteristics of the mothers

\begin{tabular}{|c|c|c|c|c|c|c|c|c|}
\hline \multirow[t]{2}{*}{ Variable } & & \multicolumn{2}{|c|}{$\operatorname{SCD}(n=100)$} & \multirow{2}{*}{\multicolumn{2}{|c|}{$\begin{array}{c}\text { Asthma }(\mathrm{n}=75) \\
\text { No. }(\%)\end{array}$}} & \multirow{2}{*}{\multicolumn{2}{|c|}{$\begin{array}{c}\text { AMI }(\mathrm{n}=75) \\
\text { No. }(\%)\end{array}$}} & \multirow[t]{2}{*}{ P-value } \\
\hline & & No. & $(\%)$ & & & & & \\
\hline \multirow[t]{4}{*}{ Mother's age (years) } & $25-30$ & 9 & 9 & 10 & 13 & 17 & 23 & 0.062 \\
\hline & $31-35$ & 19 & 19 & 22 & 29 & 14 & 19 & \\
\hline & $36-40$ & 37 & 37 & 20 & 27 & 27 & 36 & \\
\hline & $>40$ & 35 & 35 & 23 & 31 & 17 & 23 & \\
\hline \multirow{4}{*}{$\begin{array}{l}\text { Mother's level } \\
\text { of education }\end{array}$} & None & 38 & 38 & 24 & 32 & 20 & 27 & 0.268 \\
\hline & Primary & 21 & 21 & 12 & 16 & 18 & 24 & \\
\hline & Secondary & 25 & 25 & 30 & 40 & 22 & 29 & \\
\hline & Tertiary & 16 & 16 & 9 & 12 & 15 & 20 & \\
\hline \multirow{4}{*}{$\begin{array}{l}\text { Father's level } \\
\text { of education }\end{array}$} & None & 23 & 23 & 12 & 16 & 7 & 9 & 0.246 \\
\hline & Primary & 26 & 26 & 17 & 23 & 17 & 23 & \\
\hline & Secondary & 21 & 21 & 21 & 28 & 25 & 33 & \\
\hline & Tertiary & 30 & 30 & 25 & 33 & 26 & 35 & \\
\hline \multirow{3}{*}{$\begin{array}{l}\text { Mother's } \\
\text { occupational groups }\end{array}$} & Skilled & 17 & 17 & 14 & 19 & 17 & 23 & 0.314 \\
\hline & Semi skilled & 22 & 22 & 25 & 33 & 22 & 29 & \\
\hline & Unskilled & 61 & 61 & 36 & 58 & 36 & 58 & \\
\hline \multirow{3}{*}{$\begin{array}{l}\text { Father's occupational } \\
\text { groups }\end{array}$} & Skilled & 31 & 33 & 29 & 41 & 28 & 37 & 0.525 \\
\hline & Semi skilled & 32 & 34 & 22 & 31 & 29 & 39 & \\
\hline & Unskilled & 32 & 34 & 20 & 28 & 17 & 22 & \\
\hline \multirow{2}{*}{$\begin{array}{l}\text { Mother's marital } \\
\text { status }\end{array}$} & Married & 93 & 93 & 70 & 93 & 74 & 99 & 0.196 \\
\hline & others & 7 & 7 & 5 & 7 & 1 & 1 & \\
\hline \multirow{3}{*}{$\begin{array}{l}\text { Mother's years } \\
\text { of marriage }\end{array}$} & $<10$ & 6 & 6 & 7 & 9 & 9 & 12 & 0.434 \\
\hline & $10-20$ & 61 & 62 & 47 & 63 & 50 & 67 & \\
\hline & $>20$ & 32 & 32 & 20 & 27 & 16 & 21 & \\
\hline \multirow[t]{2}{*}{ Type of family } & Monogamy & 59 & 60 & 51 & 68 & 53 & 71 & 0.270 \\
\hline & Polygamy & 40 & 40 & 24 & 32 & 22 & 29 & \\
\hline \multirow{2}{*}{$\begin{array}{l}\text { Mothers No. } \\
\text { of children }\end{array}$} & 5 or less & 75 & 75 & 53 & 71 & 53 & 71 & 0.754 \\
\hline & $6 \&$ above & 25 & 25 & 22 & 29 & 22 & 29 & \\
\hline \multirow{2}{*}{$\begin{array}{l}\text { Fathers No. } \\
\text { of children }\end{array}$} & 5 or less & 57 & 57 & 42 & 56 & 42 & 56 & 0.988 \\
\hline & $6 \&$ above & 43 & 43 & 33 & 44 & 33 & 44 & \\
\hline \multirow{2}{*}{$\begin{array}{l}\text { Adequacy of } \\
\text { husband's support }\end{array}$} & Yes & 78 & 82 & 64 & 90 & 65 & 92 & 0.171 \\
\hline & No & 17 & 18 & 7 & 10 & 6 & 9 & \\
\hline \multicolumn{2}{|l|}{ Mean age of mothers } & \multicolumn{2}{|c|}{39.010} & \multicolumn{2}{|c|}{37.680} & \multicolumn{2}{|c|}{36.907} & 0.784 \\
\hline \multicolumn{2}{|c|}{ Mean No. of mothers' children } & \multicolumn{2}{|c|}{4.680} & \multicolumn{2}{|c|}{4.600} & \multicolumn{2}{|c|}{4.773} & 0.804 \\
\hline \multicolumn{2}{|c|}{ Mean No. of fathers' children } & \multicolumn{2}{|c|}{6.380} & \multicolumn{2}{|c|}{6.027} & 6.12 & & 0.090 \\
\hline
\end{tabular}

$\%$ of $(\mathrm{n})$ in column brackets to the nearest whole number

$\mathrm{P}$-value $<0.05$ is significant 
Table 2

Comparison of some social effects of the three diseases on the family (mothers) of the study and control groups

\begin{tabular}{|c|c|c|c|c|c|c|}
\hline \multirow[t]{2}{*}{ Variable } & & \multicolumn{2}{|c|}{ Nil effect } & \multicolumn{2}{|c|}{ Some effects } & \multirow[t]{2}{*}{ P-value } \\
\hline & & No. & $(\%)$ & No. & $(\%)$ & \\
\hline \multirow[t]{3}{*}{ Financial effect } & SCD & 6 & 6 & 94 & 94 & \multirow[t]{3}{*}{0.000} \\
\hline & Asthma & 17 & 23 & 58 & 77 & \\
\hline & AMI & 36 & 48 & 39 & 52 & \\
\hline \multirow[t]{3}{*}{ Time consumption } & SCD & 11 & 11 & 89 & 89 & \multirow[t]{3}{*}{0.000} \\
\hline & Asthma & 27 & 36 & 48 & 64 & \\
\hline & AMI & 37 & 49 & 38 & 51 & \\
\hline \multirow[t]{3}{*}{ Disease preventing enjoyment of life } & $S C D$ & 41 & 41 & 59 & 59 & \multirow[t]{3}{*}{0.000} \\
\hline & Asthma & 54 & 72 & 21 & 28 & \\
\hline & AMI & 58 & 77 & 17 & 23 & \\
\hline \multirow{3}{*}{$\begin{array}{l}\text { Ignoring the rest of the family to care for } \\
\text { patient }\end{array}$} & $\mathrm{SCD}$ & 47 & 40 & 53 & 53 & \multirow[t]{3}{*}{0.000} \\
\hline & Asthma & 58 & 77 & 17 & 23 & \\
\hline & AMI & 61 & 81 & 14 & 19 & \\
\hline \multirow{3}{*}{$\begin{array}{l}\text { Feeling that other children resent } \\
\text { the time spent with the patient }\end{array}$} & SCD & 83 & 83 & 17 & 17 & \multirow[t]{3}{*}{0.311} \\
\hline & Asthma & 66 & 88 & 9 & 12 & \\
\hline & AlvIl & 68 & 91 & 7 & 9 & \\
\hline \multirow[t]{3}{*}{ Extent of first aid cares at home } & SCD & 16 & 16 & 84 & 84 & \multirow[t]{3}{*}{0.040} \\
\hline & Asthma & 22 & 29 & 53 & 71 & \\
\hline & AMI & 23 & 31 & 52 & 69 & \\
\hline \multirow{3}{*}{$\begin{array}{l}\text { Extent of discussing illness with } \\
\text { patient }\end{array}$} & SCD & 24 & 24 & 76 & 76 & \multirow[t]{3}{*}{0.000} \\
\hline & Asthma & 30 & 40 & 45 & 60 & \\
\hline & $\mathrm{AMI}$ & 48 & 64 & 27 & 36 & \\
\hline \multirow[t]{3}{*}{ Using illness to seek attention } & $\mathrm{SCD}$ & 91 & 91 & 9 & 9 & \multirow[t]{3}{*}{0.809} \\
\hline & Asthma & 68 & 91 & 7 & 9 & \\
\hline & AMI & 70 & 93 & 5 & 7 & \\
\hline \multirow{3}{*}{$\begin{array}{l}\text { Using illness to manipulate to } \\
\text { get wants }\end{array}$} & SCD & 88 & 88 & 12 & 12 & \multirow[t]{3}{*}{0.292} \\
\hline & Asthma & 69 & 92 & 6 & 8 & \\
\hline & AMI & 71 & 95 & 4 & 5 & \\
\hline \multirow[t]{3}{*}{ Extent of overprotection } & $\mathrm{SCD}$ & 21 & 21 & 79 & 79 & \multirow[t]{3}{*}{0.000} \\
\hline & Asthma & 41 & 55 & 34 & 45 & \\
\hline & AMI & 53 & 71 & 22 & 29 & \\
\hline
\end{tabular}

$\operatorname{SCD}(n=100)$; Asthma $(\mathrm{n}=75)$; AMI $(\mathrm{n}=75)$

$\%$ of $(\mathrm{n})$ in row brackets to the nearest whole number

$\mathrm{P}$-value $<0.05$ is significant 
Table 3

Self Reporting Questionnaire (SRQ) items, positive responses by the mothers of the three groups of children

\begin{tabular}{|c|c|c|c|c|c|c|c|}
\hline Variable & \multicolumn{2}{|c|}{$\operatorname{SCD}(n=100)$} & \multicolumn{2}{|c|}{ Asthma $(\mathrm{n}=75)$} & \multicolumn{2}{|c|}{$\begin{array}{l}\text { AMI }(\mathrm{n}=75) \\
\text { No. }(\%)\end{array}$} & P-value \\
\hline Do you often have headaches? & 39 & 39 & 33 & 44 & 27 & 36 & 0.598 \\
\hline Is your appetite poor? & 17 & 17 & 5 & 7 & 9 & 12 & 0.120 \\
\hline Do you sleep badly? & 19 & 19 & 11 & 15 & 7 & 9 & 0.204 \\
\hline Do you feel easily frightened? & 35 & 35 & 27 & 36 & 29 & 39 & 0.880 \\
\hline Do your hands shake? & 7 & 7 & 6 & 8 & 5 & 7 & 0.947 \\
\hline $\begin{array}{l}\text { Do you feel nervous, tense or } \\
\text { worried? }\end{array}$ & 30 & 30 & 24 & 32 & 20 & 21 & 0.769 \\
\hline Is your digestion poor? & 13 & 13 & 2 & 3 & 4 & 5 & 0.026 \\
\hline $\begin{array}{l}\text { Do you have trouble thinking } \\
\text { clearly? }\end{array}$ & 7 & 7 & 3 & 4 & 7 & 9 & 0.429 \\
\hline Do you feel unhappy? & 54 & 54 & 25 & 33 & 22 & 29 & 0.001 \\
\hline Do you cry more than usual? & 18 & 18 & 8 & 11 & 7 & 9 & 0.182 \\
\hline $\begin{array}{l}\text { Do you find it difficult to enjoy } \\
\text { your daily activities? }\end{array}$ & 16 & 16 & 4 & 5 & 3 & 4 & 0.010 \\
\hline $\begin{array}{l}\text { Do you find it difficult to make } \\
\text { decisions? }\end{array}$ & 6 & 6 & 1 & 1 & 7 & 9 & 0.101 \\
\hline $\begin{array}{l}\text { Is your daily work suffering as a } \\
\text { result of illness? }\end{array}$ & 21 & 21 & 2 & 3 & 2 & 3 & 0.000 \\
\hline $\begin{array}{l}\text { Do you feel unable to play a } \\
\text { useful part in life? }\end{array}$ & 13 & 13 & 4 & 5 & 3 & 4 & 0.056 \\
\hline $\begin{array}{l}\text { Do you feel that you are a } \\
\text { worthless person? }\end{array}$ & 16 & 16 & 10 & 13 & 8 & 11 & 0.593 \\
\hline Have you lost interest in things? & 10 & 10 & 3 & 4 & 5 & 7 & 0.308 \\
\hline $\begin{array}{l}\text { Has the thought of ending your } \\
\text { life been in your mind? }\end{array}$ & 2 & 2 & 3 & 4 & 4 & 5 & 0.491 \\
\hline Do you feel tired all the time? & 11 & 11 & 8 & 11 & 7 & 9 & 0.934 \\
\hline $\begin{array}{l}\text { Do you have uncomfortable } \\
\text { feelings in your stomach? }\end{array}$ & 8 & 8 & 6 & 8 & 8 & 11 & 0.792 \\
\hline Are you easily tired? & 11 & 11 & 8 & 11 & 11 & 15 & 0.696 \\
\hline
\end{tabular}

$\%$ of $(\mathrm{n})$ in column brackets to the nearest whole number

$\mathrm{P}$-value $<0.05$ is significant. 


\section{Table 4}

Correlates of probable cases identified by SRQ and some socio-demographic variables of the mothers and significant P-values indicated

\begin{tabular}{|c|c|c|c|c|c|c|c|c|c|c|}
\hline \multirow{2}{*}{\multicolumn{2}{|c|}{ Variablel }} & \multicolumn{3}{|c|}{$\operatorname{SCD}\left(n_{1}=28\right)$} & \multicolumn{3}{|c|}{ Asthma $\left(n_{1}=15\right)$} & \multicolumn{3}{|c|}{$\operatorname{AMI}\left(n_{1}=19\right)$} \\
\hline & & $(\mathrm{N})$ & No. & $(\%)$ & $(\mathrm{N})$ & No. & $(\%)$ & & No. & $(\%)$ \\
\hline \multirow[t]{3}{*}{ Mother's age (years) } & $<30$ & 9 & 1 & 11 & 10 & 2 & 20 & 17 & 5 & 29 \\
\hline & $31-40$ & 56 & 13 & 23 & 42 & 8 & 19 & 41 & 9 & 22 \\
\hline & $>40$ & 35 & 14 & 40 & 23 & 5 & 22 & 17 & 5 & 29 \\
\hline \multirow[t]{3}{*}{ Mother's level of education } & None & 38 & 13 & 34 & 24 & 10 & $42^{* *}$ & 20 & 8 & 40 \\
\hline & Primary & 21 & 9 & $43^{*}$ & 12 & 2 & 17 & 18 & 3 & 17 \\
\hline & ¿Secondary & 41 & 6 & 15 & 39 & 3 & 8 & 37 & 8 & 22 \\
\hline \multirow[t]{3}{*}{ Father's level of education } & None & 23 & 8 & 35 & 12 & 4 & 33 & 7 & 3 & 43 \\
\hline & Primary & 26 & 9 & 35 & 17 & 7 & $41^{\star *}$ & 17 & 2 & 12 \\
\hline & ¿Secondary & 51 & 11 & 22 & 46 & 4 & 9 & 51 & 14 & 28 \\
\hline \multirow[t]{3}{*}{ Occupational group of mother } & Skilled & 17 & 1 & 6 & 14 & 0 & 0 & 17 & 5 & 29 \\
\hline & Semi-skilled & 22 & 6 & 27 & 25 & 4 & 16 & 22 & 5 & 23 \\
\hline & Unskilled & 58 & 19 & 33 & 35 & 11 & $31^{*}$ & 33 & 9 & 27 \\
\hline \multirow[t]{3}{*}{ Occupational group of father } & Skilled & 31 & 5 & 16 & 29 & 2 & 7 & 28 & 9 & 32 \\
\hline & Semi-skilled & 32 & 9 & 28 & 22 & 5 & 23 & 29 & 7 & 24 \\
\hline & Unskilled & 31 & 10 & 32 & 20 & 8 & $40^{\star \star}$ & 17 & 3 & 18 \\
\hline \multirow[t]{2}{*}{ Type of family } & Monogamy & 59 & 12 & 20 & 51 & 6 & 12 & 53 & 9 & 17 \\
\hline & Polygamy & 40 & 15 & 38 & 24 & 9 & $38^{* *}$ & 22 & 10 & $46^{* *}$ \\
\hline \multirow[t]{2}{*}{ Adequacy of husband's support } & Yes & 78 & 20 & 26 & 64 & 13 & 20 & 65 & 16 & 24 \\
\hline & No & 17 & 5 & 29 & 8 & 2 & 25 & 6 & 3 & 50 \\
\hline \multirow[t]{2}{*}{ Gender of the child } & Male & 52 & 19 & $37^{*}$ & 40 & 8 & 20 & 41 & 12 & 29 \\
\hline & Female & 48 & 9 & 19 & 35 & 7 & 20 & 34 & 7 & 21 \\
\hline \multirow[t]{2}{*}{ Age groups of the child (years) } & $7-10$ & 49 & 11 & 22 & 40 & 8 & 20 & 39 & 8 & 21 \\
\hline & $11-14$ & 51 & 17 & 33 & 35 & 7 & 20 & 36 & 11 & 31 \\
\hline \multirow[t]{2}{*}{ Child's level of education } & Primary & 66 & 17 & 26 & 46 & 11 & 24 & 47 & 12 & 25 \\
\hline & Secondary & 30 & 11 & 37 & 28 & 4 & 14 & 27 & 7 & 26 \\
\hline \multirow[t]{2}{*}{ Child's Rutter Scale A2 score } & None Cases & 70 & 14 & 20 & 56 & 8 & 14 & 50 & 8 & 16 \\
\hline & Cases & 30 & 14 & $47^{*}$ & 19 & 7 & $37^{\star}$ & 15 & 10 & $67^{*}$ \\
\hline \multicolumn{2}{|c|}{ Mean age of mothers with high SRQ scores $\left(n_{1}\right)$} & \multicolumn{3}{|c|}{40.250} & \multicolumn{3}{|c|}{37.571} & \multicolumn{3}{|c|}{36.700} \\
\hline \multicolumn{2}{|c|}{$\begin{array}{l}\text { Mean No. of children of mothers with high SRQ } \\
\text { scores }\left(n_{1}\right)\end{array}$} & \multicolumn{3}{|c|}{4.679} & \multicolumn{3}{|c|}{4.643} & \multicolumn{3}{|c|}{4.400} \\
\hline \multicolumn{3}{|c|}{$\begin{array}{l}\text { Mean No. of children of husbands of mothers with } \\
\text { high SRQ scores }\left(n_{1}\right)\end{array}$} & \multicolumn{2}{|c|}{6.643} & \multicolumn{3}{|c|}{7.143} & \multicolumn{3}{|c|}{6.950} \\
\hline
\end{tabular}

$\mathrm{N}=$ number of people in the sample population affected by the variable

$\mathrm{n}_{1}=$ is number of people in the disease group who were probable cases

$\%$ of $n_{1}$ in column brackets to the nearest whole number

${ }^{*}=\mathrm{P}<0.05 ;{ }^{* *} \mathrm{P}<0.01 ;{ }^{* * *}=\mathrm{P}<0.001$ 


\section{DISCUSSION}

In all the socio-demographic variables assessed in this study fairly similar frequency distributions were found among the groups, hence it can be safely concluded that the characteristics of the samples are generally comparable.

The basis of comparing SCD with asthma and AMI in terms of psychosocial impact is rooted in the assumption that $\mathrm{SCD}$ possess more factors known to mediate psychosocial maladjustment in physical illnesses than the other disease conditions $(8,21,22)$. The only draw back of this assumption is that these factors are highly variable within and between disease condition(s).

Of the social variables assessed as possible effects of the diseases on mothers, mothers of sicklers reported significantly higher rates over the controls in six of the variables (Table 2). The serious financial and time burdens on the families of sicklers have been described $(3,23)$. This was substantiated in this study as the mothers of sicklers scored significantly higher than the controls (combined or separately) on these items. The greater frequency and duration of interventions e.g. hospital attendance, admissions and use of routine drugs for life are possible reasons for the difference. This finding may be due to the obvious reason that money and time are needed for these interventions and for the day-to-day care of sicklers, which can be very tasking.

An important area of family functioning is the way parents relate with their ill children and the feeling of neglect this generates in the other siblings. About one in two mothers of sicklers reported ignoring the rest of the family because of the ill child, as against less than one in five of the control groups. Also, 79\% of mothers of sicklers reported overprotecting their children as against $45 \%$ of mothers of asthmatics and $29 \%$ of mothers of children with AMI. Both problems are identified risk factors in the psychopathology of psychosocial problems in chronic physical illness (9), and can lead to family dysfunction. The higher degree of severity and chronicity of SCD and the greater perceived but real fear of complications or death by mothers because of their experience of the disease may be responsible for these differences. These problems can be tackled by appropriate counselling. For mothers of sicklers, it could be best done at either SCD clinics or social meeting points like the sickle cell clubs.
The severity of the social burden of SCD can further be appreciated by the observation that about three in five mothers of sicklers reported that the disease prevented them from enjoying their lives as against one in four of the control groups. In a similar study (2), it was reported that SCD affected negatively the working lives of $80 \%$ of mothers and the marriages of $93 \%$. That study was carried out in a tertiary hospital in Ibadan and involved 30 sets of parents of sicklers.

In terms of the probable psychological morbidity in the mothers using the cut-off point of 5 , there was no significant difference between the rates in SCD 28\%, asthma 20\% and AMI 25\%. There was no significant difference when SCD was compared separately with asthma and AMI, neither was there any significant difference when asthma was compared with AMI. There was also no significant difference in the distribution of SRQ score in all the groups

A possible explanation for this finding is that mothers of AMI children may have been under some forms of unknown "acute" or "intense" pressure compared to the mothers of children with the two chronic conditions who might have developed some coping strategies over time. Another possible explanation is that psychological morbidity in the children may be a more important factor in determining high score of mothers on SRQ rather than the chronicity of illness since in all the three groups probable cases with psychological morbidity as identified by $\mathrm{CBQ}$ (Rutter Scale A2) were more likely to have mothers who were probable cases with psychological morbidity on SRQ. It would appear that psychological problem in the mother creates an environment that tips the child over into maladjustment and vice versa. Whichever way it goes the need to assess and treat both the child and his family together is strongly underscored.

Conclusive determination of the relationship between these variables and the reasons for the lack of significant difference between the three groups will require future research with larger number of subjects.

An assessment of the symptom profile on SRQ revealed that mothers of $S C D$ patients rated higher than the controls in: poor digestion, feeling unhappy, finding it difficult to enjoy daily activities and daily work suffering because of illness (Table 3 ). Since these are depressive symptoms, it would mean that 
mothers of sicklers were significantly more likely to report symptoms of depression. However, despite the $54 \%$ of mothers of sicklers who reported being unhappy only $2 \%$ reported suicidal ideation. This would suggest that the depressive symptoms were mild. In view of this finding, it is suggested that mothers of sicklers should be closely monitored for depressive illness and prompt treatment given as indicated.

One of the variables (male gender) was the only variable specific to mothers of sicklers that correlated with high score on SRQ. The male gender child has not been reported to affect score on CBQ in this setting (20). This finding was therefore a surprise. The relationship between male children and high SRQ scores may be because of the importance placed on male children in the Yoruba culture, as they are considered precious and are expected to ensure the continuity of the family lineage. This may therefore increase the concern placed on them by their mothers.

Educational level appears to have effect on psychological morbidity in this study. Low level of education was found to significantly correlate with high score on SRQ in mothers of SCD children and asthmatics. Also, low level of fathers' education significantly correlated with high score on SRQ by mothers of asthmatics. Furthermore, low level of occupational status significantly correlated with high score on SRQ by mothers of asthmatics. It is expected that low level of education would be associated with low occupational status. The influence of low educational and occupational levels on psychological morbidity of mothers may be explained in terms of lower ability to cope financially, medically and socially with their childrens' illness.

In conclusion, the findings of this study suggest that mothers of SCD children suffer significant psychosocial impairment from their children's illness. In view of this more attention should be focused on them, since their psychosocial maladjustment may aggravate their children's problems in terms of management, manageability and prognosis.

There is need to involve psychiatry unit in their care to identify and manage co-existing psychosocial problems in collaboration with other units taking care of children with physical illnesses and their mothers. This can be effectively achieved by initiating comprehensive consultation-liaison psychiatry in the hospital. Mothers should be encouraged to use modern family planning methods, which has the potential of limiting family size, limiting the risk of mothers having additional SCD children and making more resources available to the family in the long term. Also the establishment of social organisations like SCD clubs should be encouraged, as SCD children and their families can share feelings and counsel one another using such fora.

The lack of significant difference between all the groups on the SRQ score suggests that psychosocial handicap accompany all disease conditions albeit more severe in chronic types. Therefore every effort should be made to support mothers of children with chronic physical illnesses. Subsidised treatment for this group of mothers could go a long way in minimising psychosocial complications that may arise from their children's illnesses.

It is recommended that future research and training in psychosocial care of mothers of children with chronic physical illness be encouraged at all levels of health care in Nigeria.

\section{ACKNOWLEDGEMENTS}

To Prof. M.L. Adelekan who supervised the study, Dr. A.O. Oyewole and Dr. B.A. Ayinmode who helped with data collection and the latter who also assisted with manuscript development. Finally to all the mothers and children who took part in the study and to the consultants whose clinics were used for the study.

\section{REFERENCES}

1. Barbarin O.A., Whitten C.F. and Bonds S.M. Estimating rates of psychosocial problems in urban and poor children with sickle cell anaemia. Health Soc. Work. 1994; 2: 112-119.

2. Bamisaiye A., Bakare C.G.M. and Olatawura M.O. Some social-psychologic dimensions of sickle cell anaemia among Nigerians. Clin. Paed. 1974; 1: 56-59.

3: Famuyiwa O.O. and Asuni T. A standard schedule for burden on the family of sickle -cell anaemia sufferers. I. Trop. Med. Hyg. 1991; 94: 277-282.

4. Dubo S., McLean J.A., Ching A.Y.T., Wright H.L., Kauffman P.E. and Sheldon J.M. A study of relationships between family situation, bronchial asthma and personal adjustment in children. J. Paed. 1961; 59: 402-414. 
5. Sharpiro J. Family reactions and coping strategies in response to the physically ill or handicapped child: A review. Soc. Sci. Med. 1983; 14: 913-931.

6. Smilkstein G. The family APGAR: A proposal for a family function test and its use by physicians. J. Fam. Prac. 1978; 6: 1231-1239.

7. Pless I.B.Clinical assessment: Physical and psychological functioning symposium on chronic disease in children. Paed. Clin. North Amer. 1984; 1: 33-45.

8. Leventhal J.M. Psychosocial assessment of children with chronic physical disease. Symposium on chronic disease in children. Paed Clin. North Amer. 1984; 1: 71-86.

9. Olatawura M. O.Sickle-cell disease. The Psychological aspects. Afr. J. Psych. 1976; 2: 373-377.

10. Aderele W.I. Bronchial asthma in Nigerian children. Arch. Dis. Child. 1979; 54: 448-453.

11. Staudenmayer H. Parental anxiety and other psychosocial factors associated with childhood asthma. J. Chron. Dis. 1981; 34: 627-636.

12. Carey W.B. and Sibinga M.S. Avoiding paediatric pathogenesis in the management of acute minor illness. Paediat. 1972; 4: 553-561.

13. Adeodu O.O., Adekile A.D. and Alimi T. The child with sickle cell anaemia: Effects of the disease on intra family ties and emotional status. Abstracts of proceeding of $26^{\text {th }}$ Annual Conference of the Paediatric Association of Nigeria, Sagamu. January 17-21, 1995. Nig. J. Paed. 1995; 3: 67-84.

14. Abiodun O.A. Psychosocial complications and management of sickle cell disease. East Afr. Med. J. 1993; 1: 40-42.

15. McNichol K.N., William H.E., Allan J. and McAndrew I. Spectrum of asthma in children-III, psychological and social components. Brit. Med.J. 1973; 6: 16-20.
16. Tunde-Ayinmode M.F. Psychosocial impact of sickle cell disease on children and their mothers attending University of Ilorin Teaching Hospital: A controlled study. Dissertation submitted to the National Postgraduate Medical College of Nigeria in fulfilment of the award of Fellowship of the Faculty of Psychiatry. 1999.

17. Tunde-Ayinmode M.F and Adelekan M.L. Psychosocial impact of sickle cell disease in children seen at University of Ilorin Teaching Hospital, Ilorin, Nigeria. East Afr. Med. J. 2005; 2: 73-78.

18. Harding T.W., DeArango M.V., Baltazar J., et al. Mental disorders in primary health care: A study of their frequency and diagnosis in four developing countries. Investigation in a WHO collaborative study on strategies for extending mental health care. Psy. Med. 1980; 10: 231-241.

19. Abiodun O.A. Sensitivity and validity of the Self Reporting Questionnaire (SRQ) in a primary health care centre in a rural community in Nigeria. Psychopathologie Africaine. 1988 - 1989; 1: 79-88.

20. Ohaeri J.U., Odejide O.A. and Gureje O. The prevalence of psychiatric morbidity among adults attending at the five primary health care facilities of a rural community in Nigeria. Nig. Postgrad. Med. J. 1994; 1: 12-16.

21. Gortmaker S.L., Walker D.K., Weitzman M. and Sobol A.M. Chronic conditions, socio-economic risks and behavioural problems in children and Adolescents. Paediat. 1990; 3: 267-276.

22. Taylor D.C. Psychological aspects of chronic sickness. Rutter M. and Hersov (Eds.) In: Child and adolescent psychiatry modern approaches: 2nd edition. Oxford Blackwell Scientific Publication, 1985; 621.

23. Omotade O.O. Controlling sickle cell anaemia through genetic counselling. Afr. Health. 1989; 42-43. 